\title{
Preparation and characterization of a novel antimicrobial film dressing for wound healing application
}

\author{
Melissa Marques Gonçalves ${ }^{\circledR *}$, Jaqueline Carneiro, Barbara Justus, \\ Joel Toribio Espinoza, Jane Manfron Budel, \\ Paulo Vitor Farago, Josiane Padilha de Paula
}

Postgraduate Program in Pharmaceutical Sciences, State University

of Ponta Grossa, Ponta Grossa, Paraná, Brazil

\begin{abstract}
Antibacterial activity and good mechanical properties are some of the characteristics required for an appropriate film dressing. A novel polymer blend was developed for wound healing application. Twenty-four formulations using the polymers chitosan, poly(vinyl alcohol) and/or $\varepsilon$-Polylysine and the plasticizer glycerol were designed using factorial design and then the films were prepared by the casting/solvent evaporation method. Seventeen films were obtained among the twenty-four proposed formulations that were characterized by Field Emission Scanning Electron Microscopy (FE-SEM) and Fourier Transform Infrared Spectroscopy (FTIR). Mechanical properties, such as tensile strength $(\sigma)$, elongation at break $(\varepsilon)$ and Young's modulus $(Y)$ as well as antibacterial properties were determined. The best candidate was then further analyzed with regard to porosity, Water Vapor Transmission Rate (WVTR), swelling and cytotoxicity experiments. The results showed a film with semi-occlusive characteristics, good mechanical properties and no toxic. Incorporation of $\varepsilon$-Polylysine increased antibacterial activity against gram-negative (Escherichia coli) and gram-positive (Staphylococcus aureus) bacteria.
\end{abstract}

Keywords: Chitosan. Poly(vinyl alcohol). $\varepsilon$-Polylysine. Semi-occlusive dressing.

\section{INTRODUCTION}

Skin is a tissue that covers the body and it is the main barrier against external threats e.g. pathogens and mechanical shocks (Zhang Q et al., 2019; Morgado, Aguiar-Ricardo, Correia, 2015; Radner, Fischer, 2014). Loss of skin integrity can occur due to traumas, burns, surgical procedures and others (Shahzad et al., 2015; Antunes et al., 2015). Wound healing is a complex biological process that aims to reestablish the skin integrity replacing the lost tissue (Ribeiro et al., 2013;

*Correspondence: Universidade Federal do Paraná. Av. Prefeito Lothário Meissner, 632. Jardim Botânico, Curitiba, Paraná, Brazil. Phone: +5541991750311E-mail address: melissamg1106@gmail.com
Rodrigues etal.,2012; Cardoso et al., 2011). Some wounds have a self-healing capacity, but others need additional assistance for regeneration. Also, the healing process can be compromised by infections (Antunes et al., 2015; Kim et al., 2015; De Cicco et al., 2014). Therefore, after damage, skin must be covered by a wound dressing that act as barrier to prevent microorganism entry and fluid loss and to allow cell growth and gaseous exchanges (Shi et al., 2018; Li et al., 2017; Ribeiro et al., 2013). An ideal dressing must promote healing, be biocompatible, biodegradable and with antibacterial properties in addition to have suitable flexibility to cover the wound and to maximize patient comfort (Morgado, AguiarRicardo, Correia, 2015; Vowden, Vowden, 2014; Ribeiro et al., 2013; Abdelrahman, Newton, 2011; Sung et al., 2010). 
Chitosan is a natural polymer that has been extensively used for dressing production. This polymer shows desirable characteristics for a dressing such as promotion of wound healing, biocompatibility and biodegradability (Avcu et al., 2019; Dellera et al., 2014; Hermans et al., 2014; Lin et al., 2013; Hosseini et al., 2013; Giovino et al., 2012; Kim et al., 2011). Chitosan also has the ability to inhibit bacterial growth (Unnithan et al., 2014). This particularly property results from chitosan's positively charged amino groups that interact with negatively charged groups present on bacterial surface (Kong et al., 2010).

However, natural polymers show low mechanical strength. This issue can be solved by incorporating a synthetic polymer into the dressing. Poly(vinyl alcohol) (PVA) is a biodegradable and biocompatible synthetic copolymer widely used in dressing production (Ghalei, Asadi, Ghalei, 2018; Mogoşanu, Grumezescu, 2014; Kavoosi et al., 2014; Maleki, Gharehaghaji, Dijkstra, 2013; Cozzolino et al., 2012; Sung et al., 2010). The antibacterial property of chitosan can be improved by increasing the positive charges in its chain (Xiao et al., 2011). In this context, $\varepsilon$-Polylysine is a positively charged polyamine acid that shows broad spectrum antimicrobial activity (Zhang ZH et al., 2019). It is a biodegradable and non-toxic polymer that exhibits good water solubility and stability (Lopez-Pena, McClements, 2014; Zhang et al., 2012; Chang et al., 2010). In order to enhance mechanical properties, glycerol can be used in dressing formulations as a plasticizer (Ma et al., 2017; Ifuku et al., 2014; Fundo et al., 2014; Kammoun et al., 2013).

In the present study, film dressings using chitosan, glycerol, PVA and/or $\varepsilon$-Polylysine were prepared and characterized for wound healing applications.

\section{MATERIAL AND METHODS}

\section{Material}

Chitosan (medium molecular weight, $\sim 75 \%$ deacetylated), PVA (molecular weight of 13 to 23 $\mathrm{kDa}, 89 \%$ hydrolyzed), potassium bromide and 3-(4,5-dimethyl-2-thiazolyl) -2,5-diphenyl-2Htetrazolium bromide (MTT) were purchased from SigmaAldrich (São Paulo, Brazil). $\varepsilon$-Polylysine was purchased from Zhengzhou Sigma Chemical (Zhengzhou, China). Glycerol and glacial acetic acid were purchased from Biotec (São Paulo, Brazil). RPMI 1640 medium and Fetal Bovine Serum (FBS) were purchased from Vitrocell (Campinas, Brazil). Fibroblasts 3T6-Swiss Albino were obtained from Rio de Janeiro Cell Bank. Escherichia coli (NEWP 0022) and Staphylococcus aureus (NEWP 0023) were purchased from Newprov (Curitiba, Brazil). All reagents were used without further purification.

\section{Factorial Design}

In order to evaluate the mechanical properties (dependent variables), the experiments were performed using three $2^{3}$ factorial designs. Three independent variables and their influence on the films were evaluated. Each independent variable was set at two levels. The lower and upper levels are represented by $(-)$ and $(+)$, respectively (Table I). The three independent variables in the first factorial design were chitosan, PVA, and glycerol. In the second, the three independent variables were chitosan, $\varepsilon$-Polylysine, and glycerol. The three independent variables in the third factorial design were chitosan, PVA, and $\varepsilon$-Polylysine. In this case, the ratio of glycerol that best developed the previous films was fixed (Table II).

TABLE I - Values for the lower level (-) and upper level (+) of independent variables evaluated in the factorial designs

\begin{tabular}{lcc}
\hline Independent variable & $(-)(\mathbf{m L})$ & $(+)(\mathbf{m L})$ \\
\hline Chitosan solution $1.5 \% \mathrm{w} / \mathrm{v}$ & 10 & 30 \\
PVA solution $3 \% \mathrm{w} / \mathrm{v}$ & 10 & 30 \\
E-Polylysine solution 3\% w/v & 10 & 30 \\
Glycerol & 0.5 & 1 \\
\hline
\end{tabular}

PVA: poly(vinyl alcohol) 
TABLE II - Three $2^{3}$ factorial designs to films using chitosan, glycerol, PVA and/or $\varepsilon$-Polylysine

\begin{tabular}{|c|c|c|c|c|c|c|}
\hline Formulation & Chitosan $(1.5 \% \mathrm{w} / \mathrm{v})$ & & $\begin{array}{c}\text { PVA } \\
(3 \% \text { w/v })\end{array}$ & & $\begin{array}{c}\text { E-Polylysine } \\
(3 \% \mathrm{w} / \mathrm{v})\end{array}$ & Glycerol \\
\hline FD01 & $10 \mathrm{~mL}$ & $10 \mathrm{~mL}$ & & - & $0.5 \mathrm{~mL}$ & \\
\hline FD02 & $30 \mathrm{~mL}$ & $10 \mathrm{~mL}$ & & - & $0.5 \mathrm{~mL}$ & \\
\hline FD03 & $10 \mathrm{~mL}$ & $30 \mathrm{~mL}$ & & - & $0.5 \mathrm{~mL}$ & \\
\hline FD04 & $30 \mathrm{~mL}$ & $30 \mathrm{~mL}$ & & - & $0.5 \mathrm{~mL}$ & \\
\hline FD05 & $10 \mathrm{~mL}$ & $10 \mathrm{~mL}$ & & - & $1 \mathrm{~mL}$ & \\
\hline FD06 & $30 \mathrm{~mL}$ & $10 \mathrm{~mL}$ & & - & $1 \mathrm{~mL}$ & \\
\hline FD07 & $10 \mathrm{~mL}$ & $30 \mathrm{~mL}$ & & - & $1 \mathrm{~mL}$ & \\
\hline FD08 & $30 \mathrm{~mL}$ & $30 \mathrm{~mL}$ & & - & $1 \mathrm{~mL}$ & \\
\hline FD09 & $10 \mathrm{~mL}$ & - & & $10 \mathrm{~mL}$ & $0.5 \mathrm{~mL}$ & \\
\hline FD10 & $30 \mathrm{~mL}$ & - & & $10 \mathrm{~mL}$ & $0.5 \mathrm{~mL}$ & \\
\hline FD11 & $10 \mathrm{~mL}$ & - & & $30 \mathrm{~mL}$ & $0.5 \mathrm{~mL}$ & \\
\hline FD12 & $30 \mathrm{~mL}$ & - & & $30 \mathrm{~mL}$ & $0.5 \mathrm{~mL}$ & \\
\hline FD13 & $10 \mathrm{~mL}$ & - & & $10 \mathrm{~mL}$ & $1 \mathrm{~mL}$ & \\
\hline FD14 & $30 \mathrm{~mL}$ & - & & $10 \mathrm{~mL}$ & $1 \mathrm{~mL}$ & \\
\hline FD15 & $10 \mathrm{~mL}$ & - & & $30 \mathrm{~mL}$ & $1 \mathrm{~mL}$ & \\
\hline FD16 & $30 \mathrm{~mL}$ & - & & $30 \mathrm{~mL}$ & $1 \mathrm{~mL}$ & \\
\hline FD17 & $10 \mathrm{~mL}$ & $10 \mathrm{~mL}$ & & $10 \mathrm{~mL}$ & $1 \mathrm{~mL}$ & \\
\hline FD18 & $30 \mathrm{~mL}$ & $10 \mathrm{~mL}$ & & $10 \mathrm{~mL}$ & $1 \mathrm{~mL}$ & \\
\hline FD19 & $10 \mathrm{~mL}$ & $30 \mathrm{~mL}$ & & $10 \mathrm{~mL}$ & $1 \mathrm{~mL}$ & \\
\hline FD20 & $30 \mathrm{~mL}$ & $30 \mathrm{~mL}$ & & $10 \mathrm{~mL}$ & $1 \mathrm{~mL}$ & \\
\hline FD21 & $10 \mathrm{~mL}$ & $10 \mathrm{~mL}$ & & $30 \mathrm{~mL}$ & $1 \mathrm{~mL}$ & \\
\hline FD22 & $30 \mathrm{~mL}$ & $10 \mathrm{~mL}$ & & $30 \mathrm{~mL}$ & $1 \mathrm{~mL}$ & \\
\hline FD23 & $10 \mathrm{~mL}$ & $30 \mathrm{~mL}$ & & $30 \mathrm{~mL}$ & $1 \mathrm{~mL}$ & \\
\hline FD24 & $30 \mathrm{~mL}$ & $30 \mathrm{~mL}$ & & $30 \mathrm{~mL}$ & $1 \mathrm{~mL}$ & \\
\hline
\end{tabular}

PVA: poly(vinyl alcohol) 


\section{Preparation of the Films}

Using the factorial designs, twenty-four films were prepared by casting/solvent evaporation method (Murguía-Flores et al., 2016; Tan et al., 2008; Azad et al., 2004). Chitosan solution $(1.5 \% \mathrm{w} / \mathrm{v})$ was prepared by dissolving it in $0.5 \%(\mathrm{v} / \mathrm{v})$ aqueous glacial acetic acid. Solutions of PVA $(3 \% \mathrm{w} / \mathrm{v})$ and $\varepsilon$-Polylysine $(3 \% \mathrm{w} / \mathrm{v})$ were prepared by their dissolution in deionized water. According to the Table II, chitosan, PVA and $\varepsilon$-Polylysine solutions and glycerol were mixed under magnetic stirring, at $45^{\circ} \mathrm{C}$ and $3 \mathrm{~h}$. After that, equal volumes of each formulation were transferred into polyethylene Petri dishes and dried at $37^{\circ} \mathrm{C}$, until constant weight.

\section{Characterization}

\section{Field Emission Scanning Electron Microscopy}

Surface of the obtained films and thickness of the selected film (with best mechanical and antimicrobial properties) were performed on Field Emission Scanning Electron Microscopy (FE-SEM) (Mira3 - TESCAN $\left.{ }^{\circledR}\right)$ at $5-10 \mathrm{kV}$.

\section{Fourier Transform Infrared Spectroscopy}

Chemical characterization of the obtained films was done by Fourier Transform Infrared Spectroscopy (FTIR) (IR Prestige 21 - SHIMADZU ${ }^{\circledR}$ ) in the range of $4000-400 \mathrm{~cm}^{-1}$. Potassium bromide pallet method was applied.

\section{Mechanical Properties Analysis}

Mechanical properties of obtained films were determined on Universal Mechanical Testing Machine (AG-I 10kN - SHIMADZU ${ }^{\circledR}$ ). Films samples $(40 \mathrm{~mm}$ x $15 \mathrm{~mm}$ ) were held between clamps and pulled at a rate of $1.0 \mathrm{~mm} . \mathrm{min}^{-1}$. Tensile strength $(\sigma)$, elongation at break $(\varepsilon)$ and Young's modulus (Y) were determined (Lin et al., 2013). The experiments were performed in triplicate. Statistical analysis of the data was performed using ANOVA and Tukey test at a significance level of $p<0.05$ and the results were presented as mean \pm standard deviation.

\section{Antibacterial Activity Analysis}

Antibacterial activity of obtained films was assessed by agar diffusion method (Patil et al., 2016). Suspensions of Escherichia coli and Staphylococcus aureus bacteria in a final concentration of $10^{8} \mathrm{CFU}$. $\mathrm{mL}^{-1}$ (MacFarland scale) were streaked evenly in three planes, using a cotton swab, on the surface of Petri dishes containing Mueller-Hinton agar. Films samples (6 $\mathrm{mm}$ diameter disks) were placed into Petri dishes that were incubated overnight at $37^{\circ} \mathrm{C}$. After incubation, antibacterial activities of the films were determined by measuring the inhibition zones formed. The experiments were performed in triplicate.

\section{Porosity Test}

The porosity ratio $(\mathrm{P} \%)$ of the selected film, was measured through the determination of the amount of solvent absorbed by the film sample $(20 \mathrm{~mm}$ x $20 \mathrm{~mm})$ after $1 \mathrm{~h}$ of immersion in ethanol, using Eq. 1 (Correia et al., 2013):

$P \%=\frac{W w-W d}{d_{\text {ethanol }} V_{\text {film }}} \times 100$

where, $\mathrm{W}_{\mathrm{w}}$ and $\mathrm{W}_{\mathrm{d}}$ are the weight of the wet and dry film, respectively, $d_{\text {ethanol }}$ is the density of the ethanol at room temperature and $V_{\text {film }}$ is the volume of the wet film. $V_{\text {film }}$ was determined by measuring the film thickness with a pachymeter. The experiment was performed in triplicate.

\section{Water Vapor Transmission Rate Test}

Water Vapor Transmission Rate (WVTR) measurement of the selected film was determined using a usual method (Antunes et al., 2015; Lin et al., 2013). Briefly, film samples were used to seal the opening of a glass test tube $\left(1.77 \mathrm{~cm}^{2}\right)$ containing $10 \mathrm{~mL}$ of deionized water. Tape was used to attach the film. The tubes were left in an incubator at $37{ }^{\circ} \mathrm{C}$. After $24 \mathrm{~h}$, water evaporation was determined by weight measurement. WVTR was calculated using Eq. 2:

$W V T R=\frac{W_{\text {loss }}}{A}$

where, $\mathrm{W}_{\text {loss }}$ is the weight loss of water and $\mathrm{A}$ is the area of the tube opening. Non-attached films were 
used as controls. The experiment was performed in quintuplicate.

\section{Swelling Test}

The water uptake was determined for the selected film by the following method (Hermans et al., 2014; Sung et al., 2010): film samples (20 $\mathrm{mm}$ x $20 \mathrm{~mm}$ ) were weighed. The samples were left in a beaker containing $20 \mathrm{~mL}$ of phosphate buffered saline (PBS) pH 7.4 at $37{ }^{\circ} \mathrm{C}$ for $4 \mathrm{~h}$. After this period, excess amount of PBS was removed and the film samples wet were weighed. Swelling ratio (S\%) was calculated according Eq. 3:

$S \%=\frac{W w-W d}{W d} \times 100$

where, $\mathrm{W}_{\mathrm{w}}$ and $\mathrm{W}_{\mathrm{d}}$ are the weights of the wet and dry film, respectively. The experiment was performed in triplicate.

\section{Cytotoxicity Analysis}

Cytotoxicity evaluation of the materials used for preparation of selected film was performed in vitro using MTT assay (Mosmann, 1983). Briefly, Fibroblasts 3T6-Swiss Albino in RPMI 1640, supplemented with $10 \% \mathrm{FBS}$, were seeded into 96 well culture plates $(2.5$ x $10^{5}$ cell/well) followed by incubation at $37{ }^{\circ} \mathrm{C}$ and $5 \%$ $\mathrm{CO}_{2}$ during $24 \mathrm{~h}$ for adhesion. Then, was added RPMI 1640 , supplemented with $10 \% \mathrm{FBS}$, containing the same amounts of chitosan, $\varepsilon$-Polylysine and glycerol used for selected film preparation, followed by incubation at $37{ }^{\circ} \mathrm{C}$ and $5 \% \mathrm{CO}_{2}$. After $24 \mathrm{~h}$, MTT solution $(0.5$ mg.ml ${ }^{-1}$ ) in RPMI 1640, supplemented with $10 \%$ FBS, was added and cells were incubated for $1 \mathrm{~h}$ at $37^{\circ} \mathrm{C}$ and $5 \% \mathrm{CO}_{2}$. Subsequently, DMSO was added to solubilize the formazan crystals formed and the absorbance was measured at $550 \mathrm{~nm}$ using a plate reader $\left(\mu\right.$ Quant $^{\mathrm{TM}}$ BIOTEK $^{\circledR}$ ). Statistical analysis of the data was performed using ANOVA and Tukey test at a significance level of $p<0.05$.

\section{RESULTS AND DISCUSSION}

Eight films were prepared to each factorial design. Seventeen films were obtained among the twenty-four proposed formulations (FD01, FD02, FD03, FD04, FD05, FD06, FD07, FD08, FD09, FD10, FD14, FD16, FD17, FD18, FD20, FD22, FD24). Visually, the films presented smooth surfaces, indicating homogeneity after the combination of polymers and plasticizer. All films showed a transparent appearance and were flexible.

It was observed at the images obtained by FESEM (Figure 1) that some formulations showed smooth surfaces (FD02, FD03, FD04, FD07, and FD08), some showed rough surfaces (FD01, FD05, FD06, FD09, FD10, FD14, FD16, FD17, FD20 and FD22) and others showed glycerol excess that was not incorporated into the film (FD18 and FD24), which could also be observed macroscopically. All the obtained films presented small clusters (clear dots in the images), which are speculated to be composed of not soluble portions of polymers.

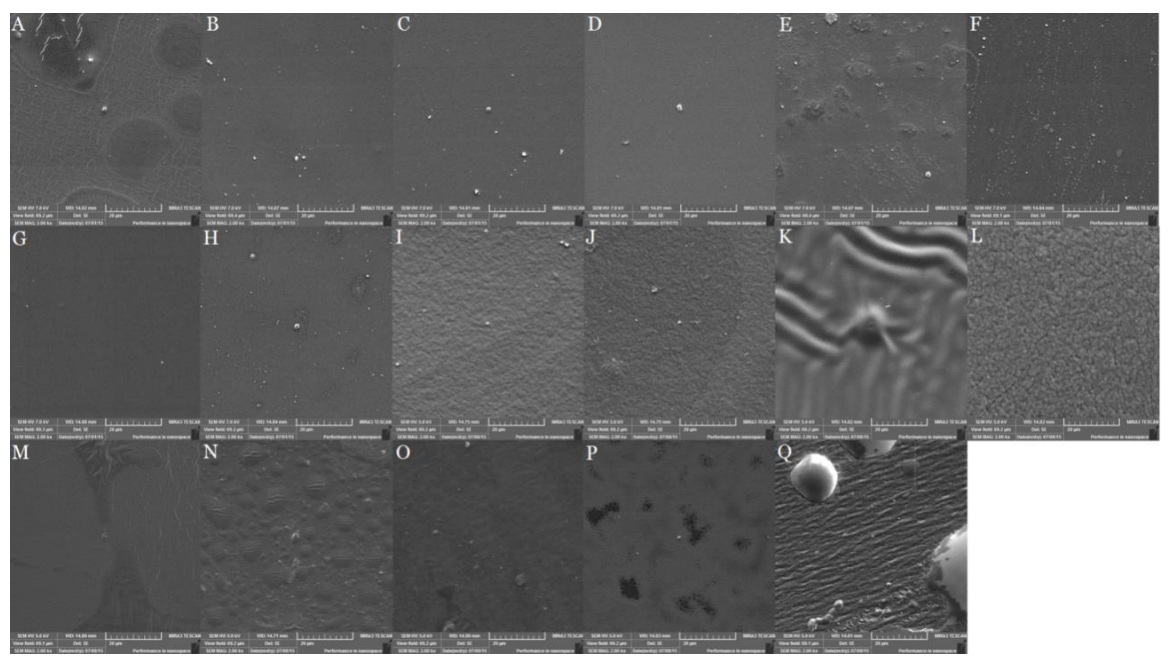

FIGURE 1 - FE-SEM surface micrographs of A) FD01; B) FD02; C) FD03; D) FD04; E) FD05; F) FD06; G) FD07; H) FD08; I) FD09; J) FD10; K) FD14; L) FD16; M) FD17; N) FD18; O) FD20; P) FD22; Q) FD24. 
FTIR was used to evaluate the chemical characteristics of the novel films. Figure 2 shows the FTIR spectra of chitosan, $\varepsilon$-Polylysine, PVA and some obtained films, as examples. The large band observed around $3351 \mathrm{~cm}^{-1}$ indicates chitosan amino and hydroxyl groups. FTIR spectrum of PVA reveals a major peak at $2858 \mathrm{~cm}^{-1}$ which is associated with $\mathrm{C}-\mathrm{H}$ broad alkyl stretching and the typical strong hydroxyl band at 3450 $\mathrm{cm}^{-1}$ for free alcohol. Amide group is a main functional group of $\varepsilon$-Polylysine. It was observed in $\varepsilon$-Polylysine spectrum characteristic amide bands at $1660 \mathrm{~cm}^{-1}$, mainly CO group stretching, and at $1564 \mathrm{~cm}^{-1}$ related to $\mathrm{NH}$ group. The analysis of each film spectra reveals the characteristic peaks of all the components used in their preparation. The FTIR spectra obtained for the films showed bands related to the same groups observed for their initial materials, which suggest that there was not formation of new covalent bonds between the polymers and the starting materials are compatible to each other.

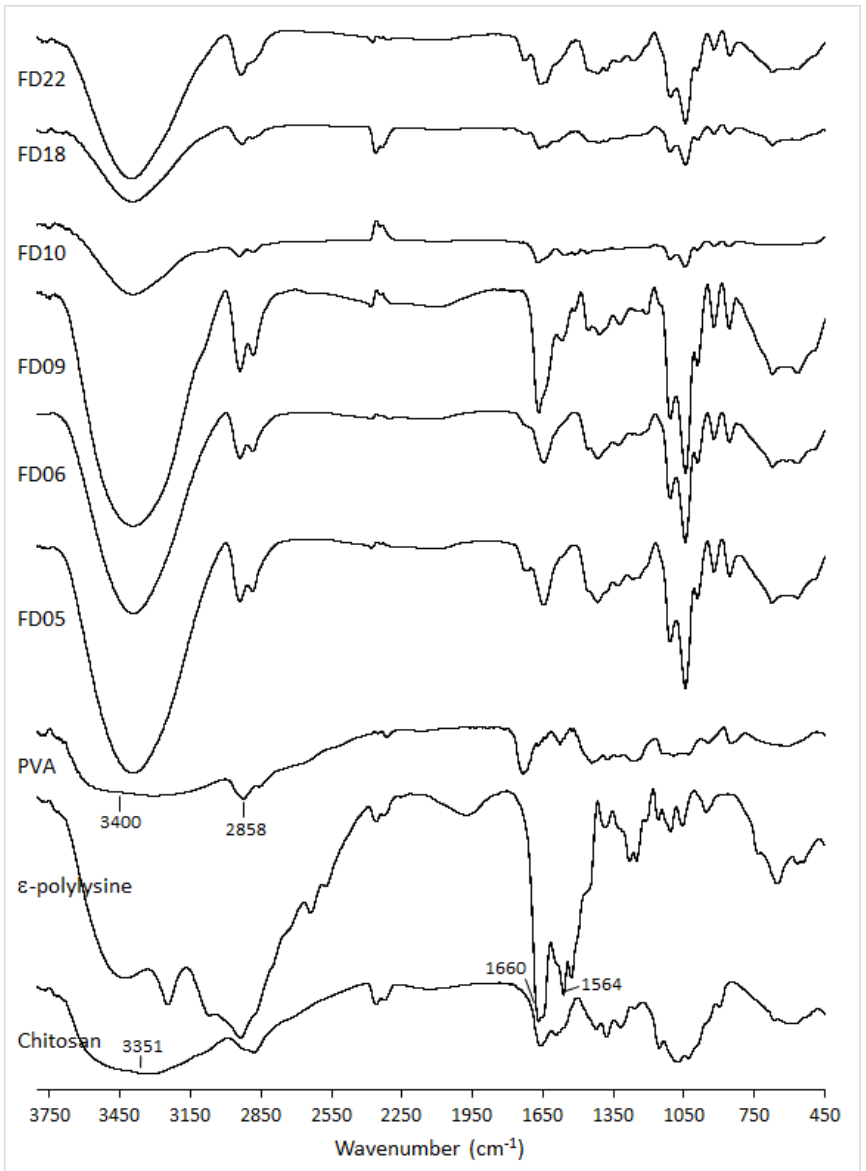

FIGURE 2 - FTIR spectra of chitosan, $\varepsilon$-Polylysine, PVA and some obtained films (FD05, FD06, FD09, FD10, FD18, FD22).
In order to investigate the mechanical properties of obtained films, tensile strength $(\sigma)$, elongation at break $(\varepsilon)$ and Young's modulus (Y) (dependent variables of factorial design) were determined and are summarized in Table III. Tensile tests are performed to evaluate the maximum stress sustained by a film (Kavoosi et al., 2014). For wound treatment, high tensile strength values are required to maintain film integrity and high elongation at break values show flexibility in order to make the application easy on skin (Morgado, AguiarRicardo, Correia, 2015). Young's modulus measure the relationship between the stress (applied force) and strain (resulting deformation) of the films.

TABLE III - Mechanical properties of obtained films

\begin{tabular}{|c|c|c|c|}
\hline Test & $\begin{array}{c}\sigma\left(\mathrm{N} / \mathbf{m m}^{2}\right. \\
\left. \pm \mathrm{SD}^{*}\right)\end{array}$ & $\varepsilon(\mathbf{m m} \pm \mathrm{SD})$ & $\begin{array}{c}\mathrm{Y}\left(\mathrm{N} / \mathbf{m m}^{2}\right. \\
\left. \pm \mathrm{SD}^{*}\right)\end{array}$ \\
\hline FD01 & $1.06 \pm 0.330$ & $43.20 \pm 15.456$ & $2.44 \pm 0.520$ \\
\hline FD02 & $5.46 \pm 0.928$ & $134.71 \pm 11.207$ & $3.66 \pm 0.162$ \\
\hline FD03 & $1.73 \pm 0.284$ & $37.96 \pm 11.165$ & $7.24 \pm 0.119$ \\
\hline FD04 & $1.78 \pm 0.539$ & $31.31 \pm 7.595$ & $7.03 \pm 1.901$ \\
\hline FD05 & $0.90 \pm 0.182$ & $27.01 \pm 6.485$ & $2.68 \pm 0.558$ \\
\hline FD06 & $1.01 \pm 0.258$ & $40.79 \pm 15.432$ & $2.67 \pm 0.219$ \\
\hline FD07 & $0.93 \pm 0.229$ & $24.19 \pm 1.623$ & $5.32 \pm 1.582$ \\
\hline FD08 & $1.18 \pm 0.376$ & $37.36 \pm 16.935$ & $3.49 \pm 0.204$ \\
\hline FD09 & $1.42 \pm 0.057$ & $60.72 \pm 9.784$ & $2.28 \pm 0.230$ \\
\hline FD10 & $3.38 \pm 1.411$ & $115.06 \pm 33.150$ & $2.30 \pm 0.255$ \\
\hline FD14 & $1.04 \pm 0.135$ & $67.75 \pm 5.621$ & $1.52 \pm 0.097$ \\
\hline FD16 & $0.54 \pm 0.160$ & $33.88 \pm 9.880$ & $1.53 \pm 0.268$ \\
\hline FD17 & $0.21 \pm 0.038$ & $20.63 \pm 3.115$ & $0.90 \pm 0.167$ \\
\hline FD18 & $1.21 \pm 0.565$ & $64.02 \pm 32.091$ & $2.03 \pm 0.233$ \\
\hline FD20 & $0.88 \pm 0.0640$ & $60.78 \pm 8.280$ & $1.77 \pm 0.174$ \\
\hline FD22 & $1.03 \pm 0.388$ & $45.45 \pm 24.384$ & $2.95 \pm 0.446$ \\
\hline FD24 & $0.71 \pm 0.182$ & $54.39 \pm 23.89$ & $1.70 \pm 0.178$ \\
\hline
\end{tabular}

*Standard deviation calculated after three experiments 
The results of the factorial design showed different values of $\sigma$ and $\varepsilon$ for the different film dressings prepared. However, in general, all films presented low values of $\mathrm{Y}$ which means that little stress cannot cause permanent deformation, implying a flexible material and suitable for the required destination. FD02 and FD10 showed the higher $\sigma$ and $\varepsilon$ values, and were significantly higher than the other films (Figure 3). Since the goal of the factorial design was to find the films with best's $\sigma$ and $\varepsilon$ values, FD02 and FD10 were considered the bests obtained films dressings.
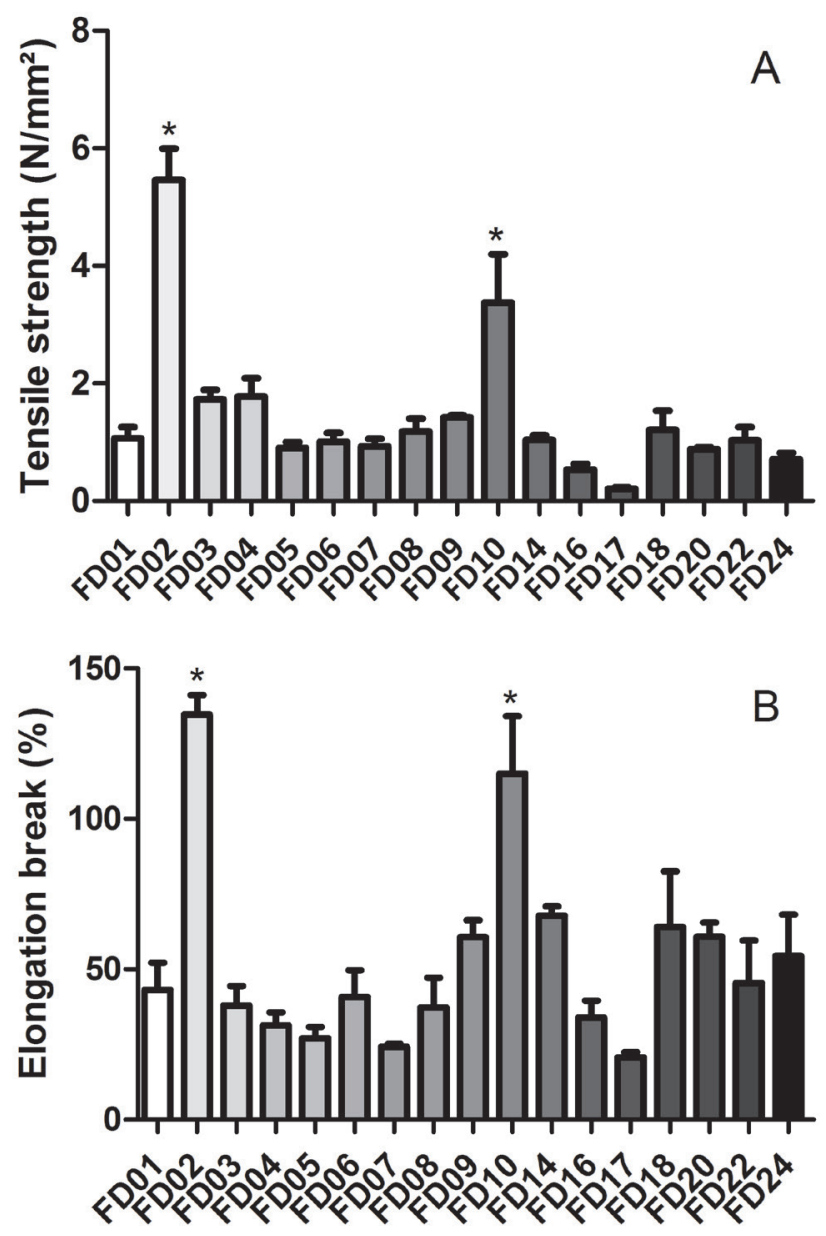

FIGURE 3 - Comparison of A) tensile strength $\left(\mathrm{N} / \mathrm{mm}^{2}\right)$ and B) elongation at break (\%) of obtained films.

Both FD02 and FD10 were obtained using chitosan upper level and glycerol lower level, which suggest that, in this ratio, glycerol produces the desired plasticizer effect. FD02 was prepared with lower level of PVA and FD10 with lower level of $\varepsilon$-Polylysine. Comparing these two films, the film prepared using PVA (FD02) showed better tensile strength and elongation at break characteristics, which confirm that PVA gives a greater improvement of the mechanical properties.

Other important property to be evaluated during the film dressing developed process is the antibacterial activity. Antimicrobial agents, such as silver sulfadiazine, have been added to film dressing formulations to offer this property, but since there are some concerns about the toxicity of these components, biocompatible agents are preferred (Morgado, Aguiar-Ricardo, Correia, 2015). Antibacterial activities of the obtained film dressings were assessed through agar diffusion method against Staphylococcus aureus and Escherichia coli bacteria. These two bacterial strains represent both gram-positive and gram-negative pathogens, respectively (Antunes et al., 2015; Karami et al., 2013). Formation of an inhibition halo $(\mathrm{mm})$ was evaluated and is shown in Table IV.

TABLE IV - Inhibition zone diameter (mm) obtained against $S$. aureus and E. coli using the films prepared

\begin{tabular}{ccc}
\hline Test & S. aureus & E. coli \\
FD01 & $6^{*}$ & 6 \\
FD02 & 6 & 6 \\
FD03 & 6 & 6 \\
FD04 & 6 & 6 \\
FD05 & 6 & 6 \\
FD06 & 6 & 6 \\
FD07 & 6 & 6 \\
FD08 & 6 & 6 \\
FD09 & 12 & 12 \\
FD10 & 10 & 10 \\
FD14 & 10 & 10 \\
FD16 & 12 & 12 \\
FD17 & 10 & 12 \\
FD18 & 10 & 10 \\
FD20 & 12 & 12 \\
FD22 & 10 & 10 \\
FD24 & 12 & 6 \\
\hline is & 6 & 6 \\
\hline & 6 & 6 \\
\hline
\end{tabular}

* $6 \mathrm{~mm}$ is the diameter of the disc 
Between the two films that presented appropriate mechanical properties (FD02 and FD10), FD02, consisting of chitosan (upper level), PVA (lower level) and glycerol (lower level), showed no inhibition halo, but no bacteria colonized the film. Whereas FD10, consisting of chitosan (upper level), $\varepsilon$-Polylysine (lower level) and glycerol (lower level), showed an inhibition halo of $10 \mathrm{~mm}$. Similar film dressing showed inhibition halos of $10.4 \mathrm{~mm}$ against $S$. aureus $7.8 \mathrm{~mm}$ against $E$. coli. (Karami et al., 2013). All the films containing $\varepsilon$-Polylysine presented the same results as FD10, which highlights the importance of $\varepsilon$-Polylysine in chitosan films for enhancing the bactericidal effect. Since the FD10 formulation showed good mechanical properties in addition to efficient antimicrobial properties, the film was further analysed.

A moist wound environment is essential to improve the healing process because it increases the reepithelialization velocity (Abdelrahman, Newton, 2011). Therefore, suitable thickness and porosity of film dressing are important to allow cellular infiltration and proliferation, as well as for gas and fluid exchange (Morgado, Aguiar-Ricardo, Correia, 2015; Antunes et al., 2015). Cross-sectional morphology and thickness (at five different regions) of FD10 were determined by FESEM (Figure 4) and the average thickness found was $82.72 \pm 21.92 \mu \mathrm{m}$. The selected film presented a porosity ratio of $27.2 \%$ and the WVTF test result confirmed the low porosity ratio found in the porosity test result. These two tests are complementary since the larger is the porosity of the film, the greater is the loss of humidity of the wound environment (high WVTF value).

The WVTR values recommended to prevent excessive dehydration are between $2000-2500 \mathrm{~mL} / \mathrm{m}^{2}$ day (Antunes et al., 2015; Sung et al., 2010). However, some available commercial film dressings, like OpSites ${ }^{\circledR}$, present WVTR around $792 \mathrm{~mL} / \mathrm{m}^{2}$ day, which is close to the data obtained for FD10 $\left(784.2 \mathrm{~mL} / \mathrm{m}^{2}\right.$ day) (Figure 5 ). This result can be influenced by structural properties of the film dressing and external conditions such as humidity and temperature (Morgado, Aguiar-Ricardo, Correia, 2015).

This data was obtained using the average value after five experiments $(0.1388 \mathrm{~mL} /$ day $)$ in Eq. 2 . This result, in addition to the measured porosity ratio, characterize the film as semi-occlusive $\left(300-800 \mathrm{~mL} / \mathrm{m}^{2} /\right.$ day) (Vowden, Vowden, 2014; Abdelrahman, Newton, 2011). There is some resistance towards the use of semiocclusive dressings on wound treatment with specific concerns related to bacterial growth. However, several studies comparing infection rates between occlusive and non-occlusive dressings have shown better result for the occlusive ones (Vowden, Vowden, 2014). It seems that these dressings prevent bacterial ingress into the wound by producing an acidic environment that retards bacterial growth. In addition, semi-occlusive films trap moisture, creating better healing environment.

Swelling tests (water uptake) allows a quantitative evaluation of the exudates absorption ability of the films which also confirms if the dressing can maintain the moist environment of the wound without allowing the accumulation of exudate, which also impairs healing. An ideal film dressing must exhibit water uptake between 100-900\% (Morgado, Aguiar-Ricardo, Correia, 2015; Lin et al., 2013). FD10 presented a swelling ratio of $147 \%$, which is within the suitable range for this application.

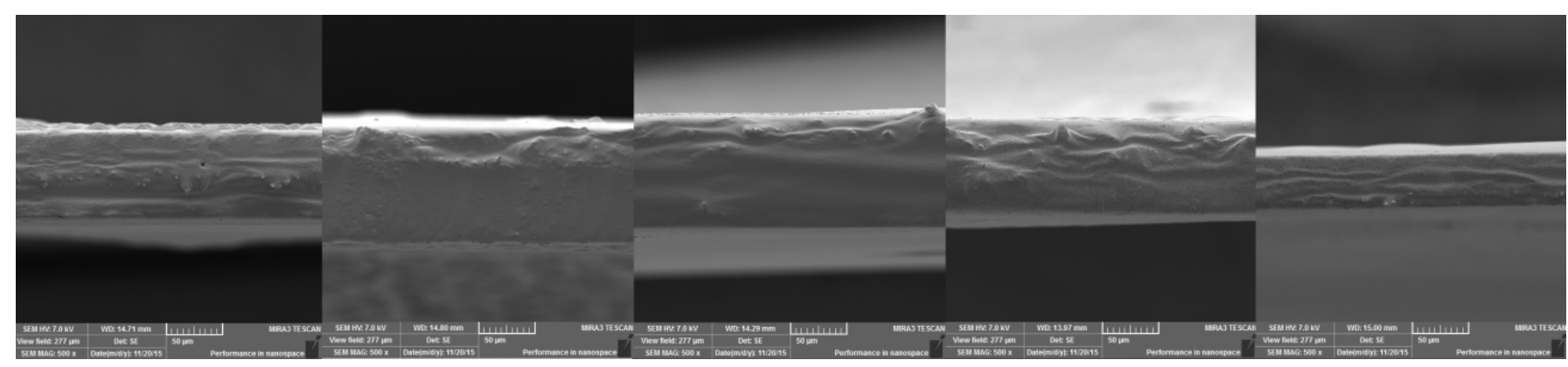

FIGURE 4 - Cross-sectional FE-SEM micrographs of FD10 in five different regions. 


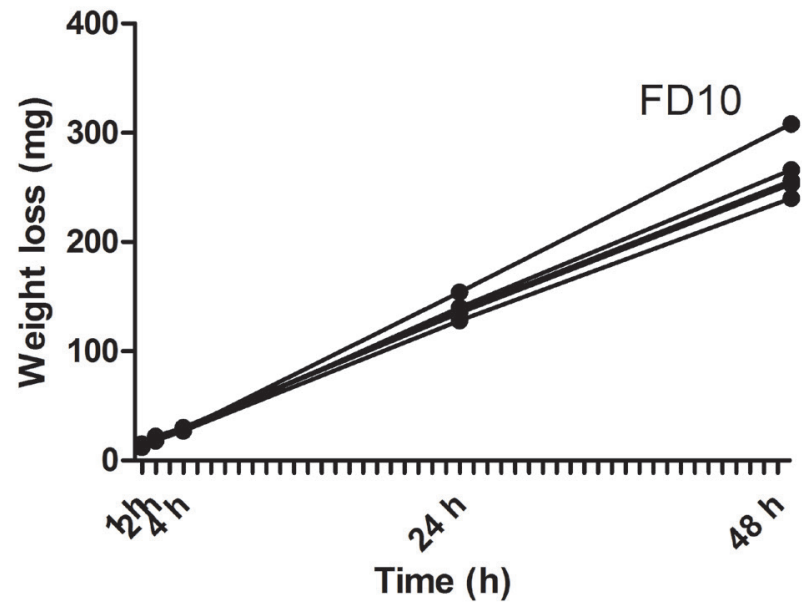

FIGURE 5 - Weight loss (mg) obtained for FD10.

For film dressing purposes, a material must be biocompatible, which can be evaluated through in vitro studies, using appropriate cell line models. In vitro cytotoxicity assay was performed to evaluate the toxicity of the initial materials used to prepare the selected wound dressing film FD10. This study was conducted using the MTT assay to determine the cell viability comparing to a control (culture medium). As shown in Figure 6, the cells showed high viability, maintaining their metabolic activity, after treatment with each initial material in the concentrations used for film preparation. There was no statistical difference between the samples and control. The cell survival was expected since the materials tested are known to be biocompatible.

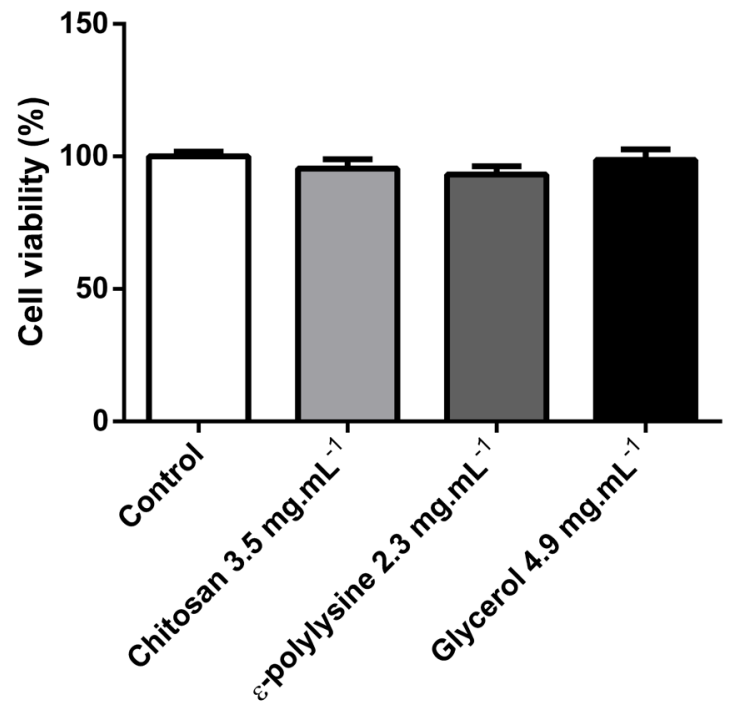

FIGURE 6 - Cell viability of fibroblasts 3T6-Swiss Albino treated with chitosan, $\varepsilon$-Polylysine and glycerol (MTT assay).

\section{CONCLUSION}

In this study were prepared seventeen film dressings using chitosan, glycerol, PVA and/or $\varepsilon$-Polylysine after factorial designs. Lower levels of glycerol seem to be sufficient for its use as plasticizer. Two formulations showed good mechanical properties for film dressing application. Between these two, the film containing $\varepsilon$-Polylysine showed greater antibacterial activity, demonstrating a synergistic effect with chitosan against both gram-positive and negative bacteria. The selected film also exhibited good swelling properties and it was determined to be a semi-occlusive film. Additionally, the absence of toxicity makes the FD10 a novel film dressing potentially effective to wound healing aplication.

\section{ACKNOWLEDGEMENTS}

The authors would like to thank C-LABMU/ PROPESP for FTIR analysis and also Dr. Milton Domingos Michel, Materials Engineering Department - State University of Ponta Grossa, for his help with evaluating the mechanical properties. The authors are grateful to CAPES for financial support.

\section{REFERENCES}

Abdelrahman T, Newton H. Wound dressings: principles and practice. Surgery. 2011;29(10):491-495.

Antunes BP, Moreira AF, Gaspar VM, Correia IJ. Chitosan/ arginine-chitosan polymer blends for assembly of nanofibrous membranes for wound regeneration. Carbohydr Polym. 2015;130:104-112.

Avcu E, Baştan FE, Abdullah HZ, Rehman MAU, Avcu YY, Boccaccini AR. Electrophoretic deposition of chitosan-based composite coatings for biomedical applications: A review. Prog Mater Sci. 2019;103:69-108.

Azad AK, Sermsintham N, Chandrkrachang S, Stevens WF. Chitosan membrane as a wound-healing dressing: characterization and clinical application. J Biomed Mater Res B Appl Biomater. 2004;69(2):216-222.

Cardoso CR, Favoreto Jr S, Oliveira LL, Vancim JO, Barban GB, Ferraz DB et al. Oleic acid modulation of the immune response in wound healing: a new approach for skin repair. Immunobiology. 2011;216(3):409-415. 
Chang SS, Lu WY, Park SH, Kang DH. Control of foodborne pathogens on ready-to-eat roast beef slurry by epsilonpolylysine. Int J Food Microbiol. 2010;141(3):236-241.

Correia TR, Antunes BP, Castilho PH, Nunes JC, Amorin MTP, Escobar IC et al. A bi-layer electrospun nanofiber membrane for plasmid DNA recovery from fermentation broths. Sep Purif Technol. 2013;112:20-25.

Cozzolino CA, Blomfeldt TOJ, Nilsson F, Piga A, Piergiovanni L, Farris S. Dye release behavior from polyvinyl alcohol films in a hydro-alcoholic medium: Influence of physicochemical heterogeneity. Colloids Surf A Physicochem Eng Asp. 2012;403:45-53.

De Cicco F, Porta A, Sansone F, Aquino RP, Del Gaudio P. Nanospray technology for an in situ gelling nanoparticulate powder as a wound dressing. Int J Pharm. 2014;473(1-2): 30-37.

Dellera E, Bonferoni MC, Sandri G, Rossi S, Ferrari F, Del Fante $\mathrm{C}$ et al. Development of chitosan oleate ionic micelles loaded with silver sulfadiazine to be associated with platelet lysate for application in wound healing. Eur J Pharm Biopharm. 2014;88(3):643-650.

Fundo JF, Fernandes R, Almeida PM, Carvalho A, Feio G, Silva CL et al. Molecular mobility, composition and structure analysis in glycerol plasticised chitosan films. Food Chem. 2014;144:2-8.

Ghalei S, Asadi H, Ghalei B. Zein nanoparticle-embedded electrospun PVA nanofibers as wound dressing for topical delivery of anti-inflammatory diclofenac. J Appl Polym Sci. 2018;135(33):1-11.

Giovino C, Ayensu I, Tetteh J, Boateng JS. Development and characterisation of chitosan films impregnated with insulin loaded PEG-b-PLA nanoparticles (NPs): a potential approach for buccal delivery of macromolecules. Int J Pharm. 2012;428(1-2):143-151.

Hermans K, Plas DV, Kerimova S, Carleer R, Adriaensens $\mathrm{P}$, Weyenberg $\mathrm{W}$ et al. Development and characterization of mucoadhesive chitosan films for ophthalmic delivery of cyclosporine A. Int J Pharm. 2014;472(1-2):10-19.

Hosseini SF, Zand M, Rezaei M, Farahmandghavi F. Twostep method for encapsulation of oregano essential oil in chitosan nanoparticles: preparation, characterization and in vitro release study. Carbohydr Polym. 2013;95(1):50-56.

Ifuku S, Ikuta A, Izawa H, Morimoto M, Saimoto H. Control of mechanical properties of chitin nanofiber film using glycerol without losing its characteristics. Carbohydr Polym. 2014;101:714-717.
Kammoun M, Haddar M, Kallel TK, Dammak M, Sayari A. Biological properties and biodegradation studies of chitosan biofilms plasticized with PEG and glycerol. Int $\mathrm{J}$ Biol Macromol. 2013;62:433-438.

Karami Z, Rezaeian I, Zahedi P, Abdollahi M. Preparation and performance evaluations of electrospun poly( $\varepsilon$-caprolactone), poly(lactic acid), and their hybrid (50/50) nanofibrous mats containing thymol as an herbal drug for effective wound healing. J Appl Polym Sci. 2013;129(2):756-766.

Kavoosi G, Nateghpoor B, Dadfar SMM, Dadfar SMA. Antioxidant, antifungal, water binding, and mechanical properties of poly(vinyl alcohol) film incorporated with essential oil as a potential wound dressing material. J Appl Polym Sci. 2014;131(20):1-8.

Kim JO, Noh JK, Thapa RK, Hasan N, Choi M, Kim JH et al. Nitric oxide-releasing chitosan film for enhanced antibacterial and in vivo wound-healing efficacy. Int J Biol Macromolec. 2015;79:217-225.

Kim KW, Min BJ, Kim Y-T, Kimmel RM, Cooksey K, Park SI. Antimicrobial activity against foodborne pathogens of chitosan biopolymer films of different molecular weights. LWT - Food Sci Technol. 2011;44(2):565-569.

Kong M, Chen XG, Xing K, Park HJ. Antimicrobial properties of chitosan and mode of action: A state of the art review. Int J Food Microbiol. 2010;144(1):51-63.

Li H, Williams GR, Wu J, Lv Y, Suna X, Wu H et al. Thermosensitive nanofibers loaded with ciprofloxacin as antibacterial wound dressing materials. Int $\mathrm{J}$ Pharm. 2017;517(1-2):135-147.

Lin WC, Lien CC, Yeh HJ, Yu CM, Hsu SH. Bacterial cellulose and bacterial cellulose-chitosan membranes for wound dressing applications. Carbohydr Polym. 2013;94(1):603-611.

Lopez-Pena CL, McClements DJ. Optimizing delivery systems for cationic biopolymers: competitive interactions of cationic polylysine with anionic $\mathrm{\kappa}$-carrageenan and pectin. Food Chem. 2014;153:9-14.

Ma Y, Xin L, Tan H, Fan M, Li J, Jia Y et al. Chitosan membrane dressings toughened by glycerol to load antibacterial drugs for wound healing. Mater Sci Eng C Mater Biol Appl. 2017;81:522-531.

Maleki H, Gharehaghaji AA, Dijkstra PJ. A novel honeybased nanofibrous scaffold for wound dressing application. J Appl Polym Sci. 2013;127(5):4086-4092. 
Preparation and characterization of a novel antimicrobial film dressing for wound healing application

Mogoşanu GD, Grumezescu AM. Natural and synthetic polymers for wounds and burns dressing. Int $\mathrm{J}$ Pharm. 2014;463(2):127-136.

Morgado PI, Aguiar-Ricardo A, Correia IJ. Asymmetric membranes as ideal wound dressings: An overview on production methods, structure, properties and performance relationship. J Membr Sci. 2015;490:139-151.

Mosmann T. Rapid colorimetric assay for cellular growth and survival: application to proliferation and cytotoxicity assays. J Immunol Methods. 1983;65(1-2):55-63.

Murguía-Flores DA, Bonilla-Ríos J, Canales-Fiscal MR, Sánchez-Fernández A. Protein adsorption through ChitosanAlginate membranes for potential applications. Chem Cent J. 2016;10:1-22.

Patil MP, Rokade AA, Ngabire D, Kim GD. Green synthesis of silvernanoparticles using water extract from galls of Rhus Chinensis and its antibacterial activity. J Cluster Sci. 2016;27(5):1737-1750.

Radner FPW, Fischer J. The important role of epidermal triacylglycerol metabolism for maintenance of the skin permeability barrier function. J Biochim Biophys Acta. 2014;1841(3):409-415.

Ribeiro MP, Morgado PI, Miguel DP, Coutinho P, Correia IJ. Dextran-based hydrogel containing chitosan microparticles loaded with growth factors to be used in wound healing. Mater Sci Eng C. 2013;33(5):2958-2966.

Rodrigues HG, Vinolo MAR, Magdalon J, Vitzel K, Nachbar RT, Pessoa AFM et al. Oral administration of oleic or linoleic acid accelerates the inflammatory phase of wound healing. J Invest Dermatol. 2012;132(1):208-215.

Shahzad Y, Louw R, Gerber M, Plessis J. Breaching the skin barrier through temperature modulations. J Control Release. 2015;202:1-13.

Shi R, Geng H, Gong M, Ye J, Wu C, Hu X et al. Longacting and broad-spectrum antimicrobial electrospun poly ( $\varepsilon$-caprolactone)/gelatin micro/nanofibers for wound dressing. J Colloid Interface Sci. 2018;509:275-284.

Sung JH, Hwang M-R, Kim JO, Lee JH, Kim YI, Kim $\mathrm{JH}$ et al. Gel characterization and in vivo evaluation of minocycline-loaded wound dressing with enhanced wound healing using polyvinyl alcohol and chitosan. Int J Pharm. 2010;392(1-2):232-240.

Tan H, Lao L, Wu J, Gong Y, Gao C. Biomimetic modification of chitosan with covalently grafted lactose and blended heparin for improvement of in vitro cellular interaction. Polym Adv Technol. 2008;19(1):15-23.

Unnithan AR, Gnanasekaran G, Sathishkumar Y, Lee YS, Kim CS. Electrospun antibacterial polyurethane-cellulose acetate-zein composite mats for wound dressing. Carbohydr Polym. 2014;102:884-892.

Vowden K, Vowden P. Wound dressings: principles and practice. Surgery. 2014;32(9):462-467.

Xiao B, Wan Y, Zhao MQ, Liu YQ, Zhang SM. Preparation and characterization of antimicrobial chitosan-N-arginine with different degrees of substitution. Carbohydr Polym. 2011;83(1):144-150.

Zhang Q, Liu X, Duan L, Gao G. Ultra-stretchable wearable strain sensors based on skin-inspired adhesive, tough and conductive hydrogels. Chem Eng J. 2019;365:10-19.

Zhang ZH, Zeng XA, Brennan CS, Ma H, Aadil RM. Preparation and characterisation of novelty food preservatives by Maillard reaction between $\varepsilon$-polylysine and reducing sugars. Int J Food Sci Technol. 2019;54(5)1-12.

Zhang Y, Zhang Q, Feng X, Li S, Xia J, Xu H. A novel agar diffusion assay for qualitative and quantitative estimation of $\varepsilon$-polylysine in fermentation broths and foods. 2012;48(1): 49-56.

Received for publication on $20^{\text {th }}$ September 2018 Accepted for publication on 11 ${ }^{\text {st }}$ April 2019 